\begin{tabular}{|l|l|l|}
\hline \multicolumn{2}{|c|}{ PublisherInfo } \\
\hline \hline PublisherName & $:$ & BioMed Central \\
\hline \hline PublisherLocation & $:$ & London \\
\hline \hline PublisherImprintName & $:$ & BioMed Central \\
\hline \hline
\end{tabular}

The thousand doors to disease

\begin{tabular}{|l|l|l||}
\hline \multicolumn{2}{|c|}{ ArticleInfo } \\
\hline \hline ArticleID & $:$ & 3653 \\
\hline \hline ArticleDOI & $:$ & $10.1186 /$ gb-2000-1-3-reports2050 \\
\hline \hline ArticleCitationID & $:$ & reports2050 \\
\hline \hline ArticleSequenceNumber & $:$ & 22 \\
\hline \hline ArticleCategory & $:$ & Web report \\
\hline ArticleFirstPage & $:$ & 1 \\
\hline \hline ArticleLastPage & $:$ & 4 \\
\hline \hline & & RegistrationDate : 2000-7-21 \\
ArticleHistory & $:$ & Received \\
\hline \hline ArticleCopyright & $:$ & BioMed Central Ltd2000-7-21 \\
\hline \hline ArticleGrants & $:$ & \\
\hline \hline
\end{tabular}




\begin{tabular}{|l|l|l||}
\hline ArticleContext & $:$ & 130591133 \\
\hline
\end{tabular}

\section{Colin Semple}

\section{Abstract}

Online Mendelian Inheritance in Man is a database of human genes and genetic disorders.

\section{Content}

Online Mendelian Inheritance in Man is a database of human genes and genetic disorders. In the foreword to his classic work Mendelian Inheritance in Man (1998, John Hopkins University Press), Victor A. McKusick cites a 17th century comment by Sir Thomas Browne on the fragility of the human constitution "... and considering the thousand doors that lead to death, do thank my God that we can die but once". McKusick's book was the first to attempt comprehensively to classify and catalog the thousand doors, with particular attention to the genetic component of human disease. It is a measure of the trend towards the digital in genetics that McKusick's book, which now thrives as a website, is the subject of a report in an online journal. The Mendelian Inheritance in Man catalog began in the early 1960s and was originally confined mainly to rare recessive disorders discovered in Old Order Amish populations. As early as 1963 the complexity of even this limited catalog necessitated computational methods for assembling and indexing data. The catalog was published online in 1987, and since then has expanded to become the central authority on phenotypic and mapping data for human genes. As of July 2000, it contained 11,778 entries and a substantial fraction of these entries represent known disease genes. For instance in February 2000, OMIM celebrated passing the 1,000 disease-gene entries mark. The information held in OMIM is extracted by human curators from the scientific and medical literature and includes reports of the genetics, physiology and biochemistry of diseases along with mapping, phenotypic and phylogenetic data on human genes.

\section{Navigation}

Text searches of the complete database are possible and may be restricted to certain fields (for example, references) and/or entries (such as those that have changed recently). Bookmarking of individual entries is possible. OMIM also curates a gene map and a 'morbid map'; the latter lists genetic diseases and their cytogenetic map locations. Both maps can also be searched with simple text queries and all data are available to download via ftp. 


\section{Reporter's comments}

\section{Timeliness}

OMIM is updated monthly. On average the last year has seen about a hundred new entries and around six hundred changes to existing entries per month.

\section{Best feature}

The annotation of gene and disease entries in OMIM is second to none, as a result of their policy of manual curation. It will be interesting to see how the database deals with the coming deluge of data, both on the identity of genes from the emerging human genome and on their associations with disease from large-scale studies of expression and single-nucleotide polymorphisms. OMIM contains an impressive array of links to sequence data and the literature via the NCBI Entrez search system. It also lists a number of useful links to locus-specific mutation databases.

\section{Wish list}

OMIM is really the only comprehensive record of how human DNA sequence variation relates to disease phenotypes so criticisms inevitably sound churlish. Having said that, certain improvements could be made. It would be nice to have better integration of the database with the currently available mapping data. For instance, if I want to find all diseases that have susceptibility loci including or close to a given marker, I have no way of easily finding them all from the database. Many, though not all, disease loci could be placed on a genetic map given the data already in OMIM. But why stop there? The more pertinent challenge now is to integrate the information in OMIM about susceptibility loci with the emerging genomic sequence and mapping resources, such as the Entrez Homo sapiens genome view genome map viewer also maintained by the NCBI.

\section{Related websites}

Disease-associated mutations are also catalogued in the Human gene mutation database (HGMD), locus-specific mutation databases are listed on the OMIM home page, and to some extent also by The genome database (GDB). The NCBI Genes and disease map provides a friendly introduction to the study of disease genes. 


\section{Table of links}

OMIM: Online Mendelian Inheritance in Man

Homo sapiens genome view

Human gene mutation database

The genome database

Genes and disease map

References

1. OMIM: Online Mendelian Inheritance in Man.

This PDF file was created after publication. 